\title{
Bioremediation of Tannery Wastewater by Aspergillus flavus SPFT2
}

\author{
Smiley Sharma and Piyush Malaviya*
}

Department of Environmental Sciences, University of Jammu, Jammu-180006 (J\&K) India

*Corresponding author

\begin{tabular}{|c|c|}
\hline & A B S T R A C T \\
\hline Keywords & \multirow{4}{*}{$\begin{array}{l}\text { Aspergillus flavus SPFT2 was isolated from untreated tannery wastewater. } \\
\text { The isolate exhibited minimum inhibitory concentration (MIC) for Cr (VI) } \\
\text { as } 500 \text { ppm. The physico-chemical analysis revealed heavy pollution load of } \\
\text { tannery effluent. After exposure to fungal treatment, the effluent exhibited } \\
55.46,61.50,77.27,89.80,98.02 \text { and } 56.50 \% \text { reduction in COD, color, } \mathrm{Cr} \\
\text { (VI), TSS, turbidity and } \mathrm{NO}_{3}^{-} \text {, respectively after six days of treatment. }\end{array}$} \\
\hline $\begin{array}{l}\text { Bioremediation, } \\
\text { Decolorization, } \\
\text { Fungi, } \\
\text { Tannery effluent. }\end{array}$ & \\
\hline Article Info & \\
\hline $\begin{array}{l}\text { Accepted: } \\
\text { 15 February } 2016 \\
\text { Available Online: } \\
\text { 10, March } 2016\end{array}$ & \\
\hline
\end{tabular}

\section{Introduction}

The problem of pollution of aquatic environments due to industrial contaminants is a serious environmental concern. The tanneries are considered as highly water intensive industries. Leather processing in a tannery generally comprises three categories: pretreatment of skin/hide (beam house operations), chrome or vegetable tanning of skin/hide (tanning operation) and finishing operations (Thanikaivelan et al., 2004). Nearly $30 \mathrm{~m}^{3}$ of wastewater is generated during processing of one tonne of raw skin/hide (Suthanthararajan et al., 2004). These wastewaters contain large quantities of chemical oxygen demand (COD), color, sodium sulphide, nitrate, chloride, chromium and suspended solids (SS) (Sharma and Malaviya, 2014).
These colored wastewaters hamper light penetration, whereas high COD results in decreased dissolved oxygen in the aquatic ecosystem. Similarly, chromium toxicity is also one of the major causes of environmental hazards caused by tannery effluents. Chromium exists in several oxidation states (I-VI), more stable as $\mathrm{Cr}$ (III). Cr (VI) is the toxic form of the element which causes severe diarrhoea, ulcers, eye and skin irritation, kidney dysfunction and probably lung carcinoma (Malaviya and Singh, 2011).

Bioremediation is a set of technologies that uses living organisms in order to degrade or transform contaminants into their less toxic forms (Vidali, 2001). It is based on the existence of microorganisms with capacity to enzymatically attack the recalcitrant 
compounds. Unlike bioremediation, the physical and chemical methods are not cost effective in terms of energy and chemical consumption besides generating large quantity of sludge which renders waste disposal problematic (Malaviya and Singh, 2014). Therefore, in the present study an attempt has been made to remediate the tannery wastewater by Aspergillus flavus SPFT2 isolated from the untreated tannery effluent.

\section{Materials and Methods}

\section{Sample Collection}

The tannery effluent samples used in the study were collected in acid-rinsed polyethylene containers from the tannery located in Central Leather Research Institute (CLRI) complex, Kapurthala Road, Jalandhar, India. The collected samples were brought to the laboratory and stored in a refrigerator at $4^{\circ} \mathrm{C}$ to be used in further studies.

\section{Isolation of Fungus from Effluent}

For the isolation of fungal strain the tannery effluent was serially diluted, centrifuged at $900 \mathrm{rpm}$ for five minutes and the supernatant was used for further enrichment in modified Lee's minimal medium without glucose $\left(0.25 \% \quad \mathrm{KH}_{2} \mathrm{PO}_{4}, \quad 0.20 \% \quad \mathrm{MgSO}_{4}\right.$, $0.50 \% \quad\left(\mathrm{NH}_{4}\right)_{2} \mathrm{SO}_{4}$ and $\left.0.50 \% \quad \mathrm{NaCl}\right)$ containing tannery sludge as sole source of carbon in Erlenmeyer flasks for three days (150 rpm, $28^{\circ} \mathrm{C}$ ).

This process was repeated several times with fresh sludge amended minimal salt medium (MSM). The final set of flasks were used for subsequent plating and isolation of fungi on sludge containing MSM plates. The $\mathrm{pH}$ of the medium was maintained at 5.3 with 100 $\mathrm{mM} \mathrm{L}^{-1}$ citrate-phosphate buffer (CardenasGonzalez and Rodrguez, 2010). The inoculated petriplates were incubated at $28^{\circ} \mathrm{C}$ for seven days. The fungal colonies appearing on MSM were picked and purified by repeated culturing on Potato Dextrose Agar (PDA) and were further identified by National Center of Fungal Taxonomy (NCFT), New Delhi. Out of the isolated fungi, Aspergillus flavus was used for the treatment of tannery wastewater (Fig. 1).

\section{Determination of Minimum Inhibitory Concentration (MIC) for Fungal Strain}

The Cr-resistance of fungal isolate was evaluated on modified Lee's minimal medium (with $0.25 \%$ glucose) supplemented with 100, 200, 300, 400, 500, 600, and 700 ppm concentrations of hexavalent chromium. The petriplates were inoculated with $8 \mathrm{~mm}$ agar plugs from young fungal colonies, pre-grown on PDA and incubated at $28^{\circ} \mathrm{C}$ for seven days (Ezzouhri et al., 2009).

The fungal growth was used as a measure of viability and was determined by measuring the change in mycelia length with the help of measuring scale at 24 hours interval from the 3rd day to the 7 th day post-inoculation (Shugaba et al., 2010). The minimum inhibitory concentration for $\mathrm{Cr}$ (VI) [MIC Cr (VI)] was defined as the concentration of hexavalent chromium that inhibits visible growth of the fungal isolate.

\section{Fungal Inoculum Development and Effluent Bioremediation}

For bioremediation studies, the fungal inoculum was prepared in the form of pellets. Erlenmeyer flasks (250 ml capacity) containing $100 \mathrm{ml}$ potato dextrose broth (PDB) and streptopenicillin (100 ppm) were inoculated with mycelial discs. These flasks were incubated at $30 \pm 1^{\circ} \mathrm{C}$ for 6 days in orbital shaker (Scigenics Biotech, India) at $150 \mathrm{rpm}$. The mycelium thus obtained was 
filtered by cheesecloth and air-dried on sterilized petriplates. The fungal pellets $(2 \%$ $\mathrm{w} / \mathrm{v})$ were inoculated in tannery wastewater amended with $0.1 \%$ glucose and $0.1 \%$ ammonium nitrate.

The $\mathrm{pH}$ was maintained at 5.3 and the flasks were incubated at $30 \pm 1^{\circ} \mathrm{C}$ in orbital shaker for six days at $150 \mathrm{rpm}$. The wastewater samples were collected at different time intervals $(2 \mathrm{~d}, 4 \mathrm{~d}$ and $6 \mathrm{~d})$ and reduction in COD, color and other pollution parameters was measured. For evaluation of fungal growth, biomass collected by centrifugation was washed thrice with sterile distilled water and dried at $80^{\circ} \mathrm{C}$ till constant weight and values were recorded.

\section{Analytical Method}

The tannery wastewater samples were analyzed for physico-chemical parameters as per standard methods for wastewater analysis. Chemical oxygen demand (COD) and total suspended solids (TSS) were determined according to American Public Health Association (APHA) methods (Greenberg et al., 1995). Color was measured spectrophotometrically $(465 \mathrm{~nm})$ according to the method of Bajpai et al. (1993). AAS The hexavalent chromium [Cr(VI)] was determined colorimetrically using the diphenylcarbazide (DPC) method (Greenberg et al., 1995).

Other parameters of the wastewater e.g. $\mathrm{pH}$, electrical conductivity (EC), and total dissolved solids (TDS) were measured using Multi Parameter Water Analyzer Kit (WTW, Germany). Sodium, chloride and nitrate ions were measured by Thermo Scientific Orion DUAL STAR ion meter while turbidity was measured by Digital Turbidity Meter (Environmental and Scientific Instruments Co., India).

\section{Results and Discussion}

\section{Isolation and Screening of Fungi}

The fungal strain Aspergillus flavus SPFT2 was isolated from untreated tannery effluent by serial dilution technique. The isolate exhibited MIC for Cr (VI) as 500 ppm. The results indicated that some native fungi have a marked adaptation to heavy metals under constant metal stress for a long time, and the toxic metals were even used as micronutrients by these growth stimulated fungi (Zhang et al., 2008).

\section{Tannery Effluent Characterization Before and After Fungal Treatment}

The combined tannery effluent used in bioremediation studies was dark grayish in color with unpleasant smell. The result indicated the mean values of $\mathrm{pH}, \mathrm{COD}$, color, $\mathrm{Cr}$, TSS, turbidity, $\mathrm{Na}^{+}, \mathrm{Cl}^{-}$and $\mathrm{NO}_{3}{ }^{-}$ were $\quad 9.16 \pm 0.20, \quad 5776 \pm 30.10$, $1984.85 \pm 12.80,12.260 \pm 0.556,1694 \pm 11.20$, $505 \pm 2.00,3080 \pm 35.60,4700 \pm 40.10$ and $600 \pm 5.00$ (Table 1). High BOD and COD values show that the effluent contained highly oxygen demanding wastes which cause the depletion of DO, which is a fundamental requirement for aquatic life (Kumar, 1989). The high levels of total suspended solids present in the tannery wastewater could be ascribed to their accumulation during the processing of finished leather (Deepa et al., 2011). These colloidal and suspended impurities cause turbidity in the receiving streams and reduce the light penetration into water and ultimately decrease the photosynthesis (Nosheen et al., 2000). Similarly, dissolved impurities like $\mathrm{Na}^{+}, \mathrm{Cl}^{-}$and $\mathrm{NO}_{3}{ }^{-}$increase salinity of the water and thus may render it unfit for irrigation or consumption. 
Table.1 Physico-Chemical Characteristics of Raw Tannery Effluent

\begin{tabular}{|l|l|}
\hline Parameters & Values \\
\hline $\mathrm{pH}$ & $9.16 \pm 0.20$ \\
\hline $\mathrm{TDS}\left(\mathrm{mgL}^{-1}\right)$ & $17650 \pm 20.10$ \\
\hline TSS $\left(\mathrm{mgL}^{-1}\right)$ & $1694 \pm 11.20$ \\
\hline Turbidity $(\mathrm{NTU})$ & $505 \pm 2.00$ \\
\hline $\mathrm{COD}\left(\mathrm{mgL}^{-1}\right)$ & $5776 \pm 30.10$ \\
\hline Color $(\mathrm{CU})$ & $1984.85 \pm 12.80$ \\
\hline $\mathrm{EC}\left(\mathrm{mS} \mathrm{cm}^{-1}\right)$ & $35.3 \pm 0.25$ \\
\hline $\mathrm{Na}^{+}\left(\mathrm{mgL}^{-1}\right)$ & $3080 \pm 35.60$ \\
\hline $\mathrm{Cl}^{-}\left(\mathrm{mLL}^{-1}\right)$ & $4700 \pm 40.10$ \\
\hline $\mathrm{NO}^{-}\left(\mathrm{mgL}^{-1}\right)$ & $600 \pm 5.00$ \\
\hline $\mathrm{Ca}^{2+}\left(\mathrm{mLL}^{-1}\right)$ & $258 \pm 12.00$ \\
\hline $\mathrm{K}^{+}\left(\mathrm{mLL}^{-1}\right)$ & $290 \pm 11.50$ \\
\hline $\mathrm{Cr}\left(\mathrm{VI}^{-1}\left(\mathrm{mgL}^{-1}\right)\right.$ & $12.260 \pm 0.556$ \\
\hline $\mathrm{Pb}(\mathrm{II})\left(\mathrm{mLL}^{-1}\right)$ & $0.965 \pm 0.0140$ \\
\hline $\mathrm{Total} \mathrm{Pb}\left(\mathrm{mgL}^{-1}\right)$ & $1.126 \pm 0.0131$ \\
\hline $\mathrm{Cu}\left(\mathrm{mgL}^{-1}\right)$ & $0.258 \pm 0.0013$ \\
\hline $\mathrm{Zn}\left(\mathrm{mgL}^{-1}\right)$ & $0.529 \pm 0.0028$ \\
\hline $\mathrm{Mn}\left(\mathrm{mLL}^{-1}\right)$ & $0.392 \pm 0.0090$ \\
\hline
\end{tabular}

Table.2 Physico-Chemical Characteristics of Tannery Effluent After Different Treatment Durations with Aspergillus Flavus Spft2

\begin{tabular}{|c|c|c|c|}
\hline \multirow[t]{2}{*}{ Parameters } & \multicolumn{3}{|l|}{$\begin{array}{c}\text { Treatment } \\
\text { duration }\end{array}$} \\
\hline & $2 d$ & 4d & 6d \\
\hline $\mathrm{pH}$ & $5.80 \pm 0.11$ & $5.25 \pm 0.16$ & $4.50 \pm 0.10$ \\
\hline $\mathrm{COD}\left(\mathrm{mg} \mathrm{L}^{-1}\right)$ & $\begin{array}{l}3648 \pm 90 \\
(36.84)\end{array}$ & $\begin{array}{l}3035.66 \pm 85 \\
(47.44)\end{array}$ & $\begin{array}{l}2572.66 \pm 72 \\
(55.46)\end{array}$ \\
\hline Color (CU) & $\begin{array}{l}1090.45 \pm 36.75 \\
(45.06)\end{array}$ & $\begin{array}{l}918.59 \pm 20.87 \\
(53.72)\end{array}$ & $\begin{array}{l}764.12 \pm 15.28 \\
(61.50)\end{array}$ \\
\hline $\mathrm{Cr}(\mathrm{VI})\left(\mathrm{mg} \mathrm{L}^{-1}\right)$ & $\begin{array}{l}5.691 \pm 0.032 \\
(61.50)\end{array}$ & $\begin{array}{l}2.786 \pm 0.023 \\
(53.28)\end{array}$ & $\begin{array}{l}0.968 \pm 0.021 \\
(77.27)\end{array}$ \\
\hline TSS $\left(\mathrm{mg} \mathrm{L}^{-1}\right)$ & $\begin{array}{l}386 \pm 12 \\
(77.21)\end{array}$ & $\begin{array}{l}224.52 \pm 10.90 \\
(86.75)\end{array}$ & $\begin{array}{l}172.80 \pm 8.72 \\
(89.80)\end{array}$ \\
\hline Turbidity (NTU) & $\begin{array}{l}112 \pm 14 \\
(77.82)\end{array}$ & $\begin{array}{l}089 \pm 8 \\
(82.38)\end{array}$ & $\begin{array}{l}010 \pm 6 \\
(98.02)\end{array}$ \\
\hline $\mathrm{Na}^{+}\left(\mathrm{mg} \mathrm{L}^{-1}\right)$ & $\begin{array}{l}2340 \pm 14.80 \\
(24.02)\end{array}$ & $\begin{array}{l}2110 \pm 12.11 \\
(31.49)\end{array}$ & $\begin{array}{l}2070 \pm 17.00 \\
(32.79)\end{array}$ \\
\hline $\mathrm{Cl}^{-}\left(\mathrm{mg} \mathrm{L}^{-1}\right)$ & $\begin{array}{l}3880 \pm 12.96 \\
(17.45)\end{array}$ & $\begin{array}{l}3830 \pm 16.56 \\
(18.51)\end{array}$ & $\begin{array}{l}3750 \pm 12.68 \\
(20.21)\end{array}$ \\
\hline $\mathrm{NO}_{3}^{-}\left(\mathrm{mg} \mathrm{L}^{-1}\right)$ & $\begin{array}{l}324 \pm 3.60 \\
(46.00)\end{array}$ & $\begin{array}{l}281 \pm 2.68 \\
(53.17)\end{array}$ & $\begin{array}{l}261 \pm 6.50 \\
(56.50)\end{array}$ \\
\hline
\end{tabular}


Fig.1 Aspergillus flavus Spft2 Colony

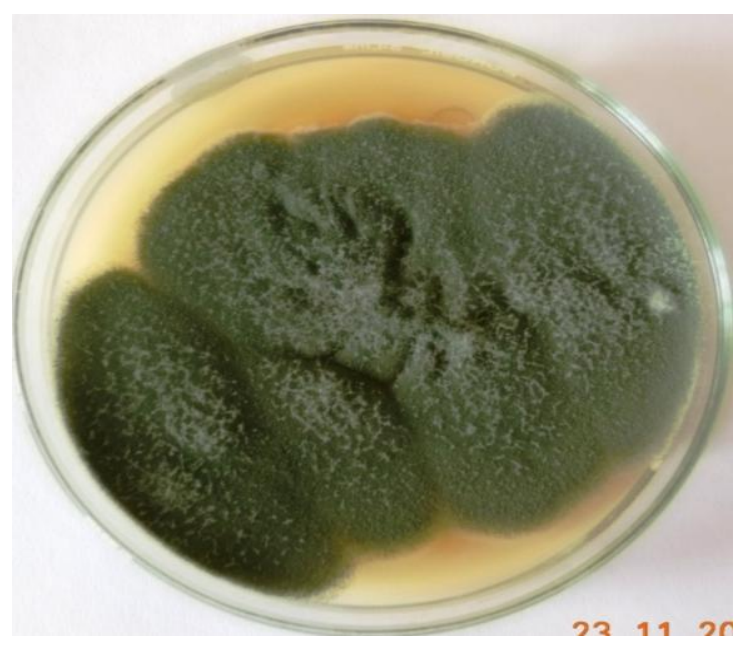

Fig.2 Reduction of Cod, Color and $\mathrm{Cr}(\mathrm{Vi})$ of Tannery Effluent After Treatment with Aspergillus flavus $\mathrm{Spft} 2$

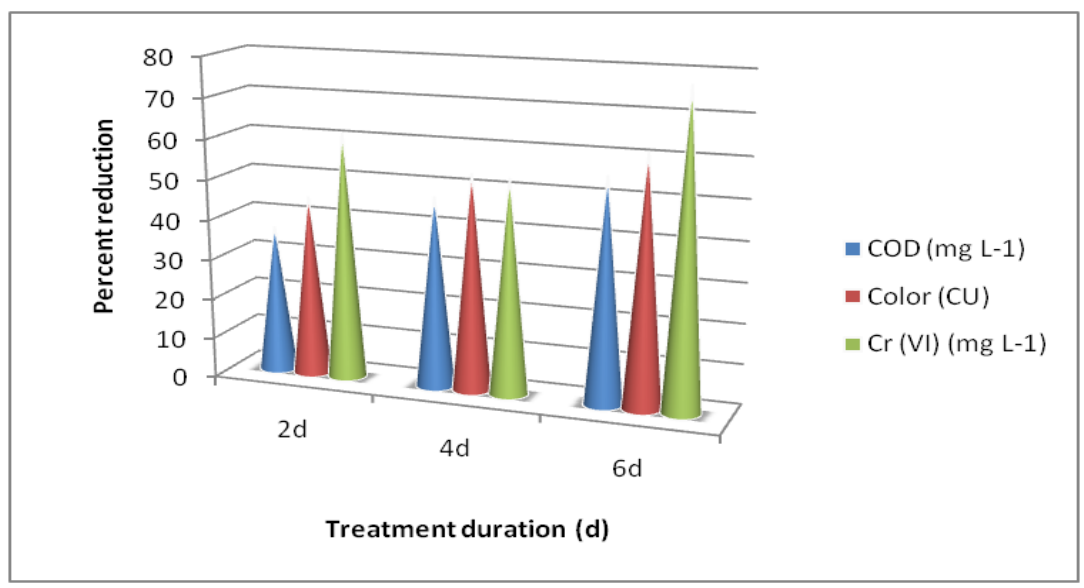

The physico-chemical characteristics of the tannery wastewater after different treatment durations with Aspergillus flavus SPFT2 are shown in Table 2 and Fig 2. After six days of fungal treatment, there was $55.46 \%$ reduction in $\mathrm{COD}$, which was attributed to uptake and degradation of organics by the fungus. On the final day of the treatment, $61.50 \%$ decolorization of the effluent was achieved which was ascribed to oxidative degradation of the dye molecules (Mohorcic et al., 2006). The tannery wastewater also marked reduction in $\mathrm{pH}$ from 5.30 to 4.50 , due to release of organic acids by the fungal isolate. The acidic environment facilitated the biosorption of $\mathrm{Cr}$ (VI) ions, resulting into $77.27 \%$ reduction of $\mathrm{Cr}(\mathrm{VI})$ on final day of the treatment.

The ions like sodium, chloride and nitrate have shown 32.79, 20.21 and $56.50 \%$ reduction on sixth day of the treatment. Likewise, TSS and turbidity have shown 89.80 and $98.02 \%$ reduction, which was ascribed to entrapment of suspended solid particles by the filamentous fungi (FakhrulRazi and Molla, 2007).

In conclusion, Aspergillus flavus SPFT2 isolated from untreated tannery effluent 
exhibited detoxification of tannery wastewater. The treatment of tannery effluent with Aspergillus flavus resulted in the reduction of COD, color, $\mathrm{Cr}(\mathrm{VI})$, total suspended solids (TSS), turbidity, $\mathrm{Na}+, \mathrm{Cl}^{-}$ and $\mathrm{NO}_{3}{ }^{-}$in the order of 55.46, 61.50, 77.27, $89.80,98.02,32.79,20.21$ and $56.50 \%$, respectively after six days of duration. For improved commercial use of the fungus, immobilization on suitable carrier is recommended.

\section{Acknowledgement}

The first author (SS) acknowledges the Junior Research Fellowship (JRF) supported by UGC. The corresponding author (PM) gratefully acknowledges the financial support provided by Department of Biotechnology, Government of India in the form of research project.

\section{References}

Bajpai, P., Mehna, A., Bajpai, P.K. 1993. Decolorization of Kraft bleach plant effluent with white-rot fungus Tramates versicolor. Process Biochemistry, 28: 377-384.

Cardenas-Gonzalez, J.F., Rodrguez, I.A. 2010. Hexavalent Chromium removal by a Paecilomyces sp. fungal strain isolated from environment. Bioinorganic and Applied Chemistry, Article I.D. 676243, 1-6.

Deepa, S., Valivittan, K.,Vincent, I., Tharadevi, $\quad$ C.S. 2011. Characterisation of tannery effluent, Thirumudivakkam, Chennai, Tamil Nadu. J. Basic App. Biol., 5: 265270.

Ezzouhri, L., Castro, M., Moya, M., Espinola, F., Lairini, K. 2009. Heavy metal tolerance of filamentous fungi isolated from polluted sites in Tangier, Morocco. Afri. J. Microbiol. Res., 3: 35-48.

Fakhrul-Razi, A., Molla, A.H. 2007. Enhancement bioseparation and dewaterability of domestic wastewater sludge by fungal treated dewatered sludge. J. Hazardous Materials, 147: 350-356.

Greenberg, A.E., Connors, J.J., Jenkins, D., Franson, M.A. 1995. Standard Methods for the Examination of Water and Wastewater, 15th ed. American Public Health Association, Washington, DC.

Kumar, A. 1989. Environmental chemistry, Wiley Eastern Limited, New Delhi, India.

Malaviya, P., Singh, A. 2011. Physicochemical technologies for remediation of chromium-containing waters and wastewaters. Critical Rev. Envi. Sci. Tech., 41: 11111172.

Malaviya, P., Singh, A. 2014. Bioremediation of chromium solutions and chromium containing wastewaters. Critical Reviews in Microbiology. 10/2014; doi:10.3109/104084ix.2014.974501.

Mohorcic, M., Teodorovic, S., Golob, V., Friedrich, J. 2006. Fungal and enzymatic decolorization of artificial textile dye baths. Chemosphere, 63: 1709-1717.

Nosheen, S., Nawaz, H., Rehman, K. 2000. Physico-chemical characterization of effluents of local textile industries of Faisalabad-Pakistan. Int. J. Agri. Biol., 2: 232-233.

Sharma, S., Malaviya, P. 2014. Bioremediation of tannery wastewater by chromium resistant fungal isolate Fusarium chlamydosporium SPFS2-g. Current World Envi., 9: 721-727. 
Shugaba, A., Nok, A.J., Ameh, D.A., Lori, J.A. 2010. Studies on growth of some filamentous fungi in culture solutions containing hexavalent chromium. Int. J. Biotechnol. Biochem., 6: 715-722.

Suthanthararajan, R., Ravindranath, E., Chitra, K., Umamaheswari, B., Ramesh, T., Rajamani, S. 2004. Membrane application for recovery and reuse of water from treated tannery wastewater. Desalination, 164: 151-156.
Thanikaivelan, P., Jonnalagadda, R.R., Balachandran, N.U., Ramasami, T. 2004. Progress and recent trends in biotechnological methods for leather processing. Trends in Biotechnol., 22: $181-188$.

Vidali, M. 2001. Bioremediation. An overview. Pure App. Chem., 73: 1163-72.

Zhang, Y., Liu, M., Shi, X., Zhao, Z. 2008. Dark septate endophyte (DSE) fungi isolated from metal polluted soils: their taxonomic position, tolerance, and accumulation of heavy metals in vitro. J. Microbiol., 46: 624-632.

\section{How to cite this article:}

Smiley Sharma and Piyush Malaviya. 2016. Bioremediation of Tannery Wastewater by Aspergillus flavus SPFT2. Int.J.Curr.Microbiol.App.Sci. 5(3): 137-143. doi: http://dx.doi.org/10.20546/ijcmas.2016.503.018 